\title{
Public HISTORIES OF AustRALIAN AND BRITISH WOMEN'S SUFFRAGE: SOME COMPARATIVE ISSUES ${ }^{1}$
}

\author{
HILDA KEAN
}

Public History ReVIEW, VOL 14, 2007, PP1-24

T he close links between activists involved in the British and Australian women's suffrage movements of the late nineteenth and early twentieth centuries have been acknowledged in several ways. The Australian success helped inform the continuing struggle in Britain; the imaginative forms of campaigning in Britain helped inspire Australian feminists in their subsequent endeavours. ${ }^{2}$ Australia, of course, was one of the first countries to grant the majority of its female citizens the vote in 1902 after a campaign lasting over 40 years. ${ }^{3}$ South Australia and Western Australia had already granted (white) women the vote: at Federation arguments had been made against joining the Australian Commonwealth if women were not to be enfranchised at a national level. ${ }^{4}$ The 1902 Act had allowed women to vote in federal elections; by 1908 white women in all states had won the right to vote although Aboriginal voters were excluded from the federal franchise until enfranchised by state governments. ${ }^{5}$ (In Western Australia and Queensland, Aboriginal people did not receive the vote until 1962). ${ }^{6}$

The campaign in Britain had taken considerably longer to achieve. Anne Knight and Catherine Barmby had first promoted the female vote within the Chartist movement (although the Chartists did not incorporate demands for the adult franchise in the Charter). ${ }^{7}$ The first parliamentary petition for women's suffrage, containing 1499 signatures, was presented by John Stuart Mill and Henry Fawcett in June $1866^{8}$ although many of the feminists, who became active as the nineteenth century turned into the twentieth century, had participated in earlier radical or feminist mass campaigns, for example against the Contagious Diseases Acts, during the 1870s. ${ }^{9}$ A limited form of local franchise had been granted to some women from 1869 and women were permitted to be elected to school boards, boards of guardians and, later, parish and district councils. ${ }^{10}$ It was not until 1928, however, that finally all women (and men), irrespective of age, academic qualification or marital status, were permitted to vote. ${ }^{11}$ The main organisations responsible for this were the National Union of Women's 
Suffrage Societies, which arose from a reunification of the suffrage movement in the $1890 \mathrm{~s},{ }^{12}$ traditionally seen as constitutionalist in their approach and called suffragist. The so-called militant suffragettes were organised mainly in the Women's Social and Political Union (WSPU) and Women's Freedom League (WFL) both formed in the early years of the twentieth century. Some recent academic work, however, has discussed both the ways in which campaigning at least at a local level crossed organisational divisions of 'constitutionalist' and 'militant' and certainly there were some aspects of common approaches to campaigning, including the production of professionally designed banners and carefully orchestrated demonstrations. ${ }^{13}$

Much has been written about women's suffrage campaigns in Australia and Britain. ${ }^{14} \mathrm{~A}$ recent collection of academic articles on British suffrage, for example, listed in four pages of densely packed footnotes hundreds of recent publications ${ }^{15}$ and suffrage continues to be an important focus of interest for feminist historians. Yet little attention has been paid to what might be called the public history of suffrage, that is the ways in which suffrage has been popularly seen and represented and how such histories were constructed and developed. Certainly, in Britain popular understandings thrive especially concerning militant suffrage. Through popular forms of knowledge including local histories, family stories, tourist trails and fiction, suffrage history has been created and 'remembered' for different generations. A recent BBC television poll, for example, of the 'top 100 Britons' placed Emmeline Pankhurst, leader of the Women's Social and Political Union, at 27, just above William Wilberforce (and below former Beatle Paul McCartney at 19). ${ }^{16}$ Moreover, school history syllabuses and even the most conventional university history courses cover, in some way, the history of women's suffrage. ${ }^{17}$ But there has been scant analysis of the reasons for such interest.

The conventional view that 'in comparison with the United Kingdom, the Australian colonies granted votes to women readily and quietly, without Primrose Leagues, suffragette suicides or chains on railings ${ }^{, 18}$ as a rationale for an apparent lack of popular attention in Australia, has been debunked in recent years. From at least the 1970s the importance of women's suffrage in Australia has been acknowledged. As Anne Summers argued in her popular Damned Whores and God's Police, the Australian feminist campaign for the vote became 'symbolic of the self-determination which women sought in all areas of life'. ${ }^{19}$ Academic work on Australian women's suffrage has developed and increased. Marilyn Lake, for example, has recognised the role of suffrage in Australian history discussing different suffrage organisations and individual personalities in her history of Australian feminism. ${ }^{20}$ In overview texts such as Stuart Macintyre's A Concise History of Australia the campaign for women's suffrage is acknowledged as an important element in the making of Australian society ${ }^{21}$ or, as Jill Roe has argued, 'woman's suffrage is integral to the rise of what is one of the world's oldest and most stable liberal democracies'. 22

But although the past Australian campaign has been analysed in academic texts, in common with the British experience much less attention has been paid to the way the movement has been subsequently portrayed within a public history context. Audrey 
Oldfield's 1992 study of Australian woman suffrage ${ }^{23}$ had suggested that suffrage had been forgotten - until the publication of her book - and sought to reverse that situation through a comprehensive documentation of the circumstances of the different stages of campaigns in different Australian states. Her work, however, essentially ended with the winning and implementation of the vote; it did not analyse the ways in which the campaign was subsequently remembered - or forgotten. In similar vein although Barbara Caine's Australian feminism: A companion ${ }^{24}$ is a laudable project aiming to shed light on a wide range of Australian feminisms past and present and to celebrate women activists, scant attention is paid to discussing the ways in which suffrage has been reinvented for a contemporary audience. ${ }^{25}$

Given the lack of discussion of ways in which women's suffrage has been created as public history in both an Australian and British context I want to raise some initial questions about public history approaches to suffrage. I will suggest that in both Britain and Australia the popular memory of the campaign for women's suffrage has been created, at least in part, by the collecting practices of individuals and feminist organisations. Moreover, the existence of different forms of material culture - including photographs, paintings and artefacts - has provided a basis upon which different generations can create histories of feminism for their own times. While noting the differences, as well as similarities, between the Australian and British experience of actual campaigns for women's franchise, I suggest that the wider - and arguably different - context of forms of cultural representation had a strong influence on the ways in which public histories were created and suffrage was 'remembered'.

\section{Differences in Situating Suffrage?}

Current interest in Britain stems partly from the nature of the tactics of the suffrage movement - and the publicity seeking actions of members of the WSPU - such as the slashing of Velázquez's The Toilet of Venus (the 'Rokeby Venus') in the National Gallery in London. ${ }^{26}$ But it is also based on the way in which activists in all the main suffrage organisations saw their politics historically and sought to ensure that their actions would be remembered. Through preserving material from the franchise campaign and creating commemorative forms in the landscape, both 'constitutionalists' and 'militants' helped create suffrage history - by their own actions.

Although the leader of the WSPU, Emmeline Pankhurst, joined the Conservative Party in 1926, standing for a parliamentary seat in the unlikely working-class district of Whitechapel in East London, ${ }^{27}$ the political and cultural origins of the WSPU were in the Labour movement's traditions and forms of spectacle. ${ }^{28}$ The feminists' emphasis on banners, slogans and particularly iconography could be traced back to at least the traditions established by the Chartist movement of the 1830s and 1840s, which in turn had been re-appropriated by the new socialist movement of the $1880 \mathrm{~s}$ and $1890 \mathrm{~s}^{29}$ 
Feminist iconography was new but the idea of banners with slogans - including the poetry of Shelley from which the WSPU slogan 'Deeds not Words' originated or 'Who would be free themselves must strike the blow' from Byron - emanated from the Chartist movement. ${ }^{30}$ It was not simply that suffrage feminists were using tried and tested methods of campaigning but that they were consciously placing themselves in the context of the earlier, socialist movement. The self-location in a particular historical continuum was adapted to create a particular sense of political identity. One of the reasons that newspapers and leaflets, objects such as badges, sashes and fund-raising china, banners and auto/biographies survive is the feminists' strong sense that their political actions would, indeed had to, be significant historically. Activists also realised that knowledge of their political and cultural role would be certain to disappear if they themselves did not create, remember and record their own histories. Such women might be said to be conscious public historians of their own actions.

Clearly some tactics of Australian suffrage activists were also taken from earlier movements. These included petitioning parliament, ${ }^{31}$ opposition to paying taxes without representation, ${ }^{32}$ lobbying political representatives, ${ }^{33}$ organising public meetings and letters to the press. ${ }^{34}$ The Australian movement, however - as Rose Scott had argued was deliberately different to the British militant model: 'Brute force', as Rose Scott put it, 'and intellectual force have in the past dominated the world. Let us contain both these forces with moral force. The safeguard of the nation will then rest on the individual conscience of its women'. ${ }^{35}$ An implicit consequence of this political strategy was the rejection of visually engaging activities (such as those reproduced in the British national and local press and in the feminists' own fund-raising postcards). Media attention, as well as feminists' own photographing of their actions, ensured that many visual representations of British suffrage activities exist. ${ }^{36}$ These include photographs of arrests, demonstrations in which women dress in particular colours and even fundraising bazaars.

Photographs also exist of the Australian movement, particularly in the photographic collection of the National Library in Canberra that includes, for example, a number of images of leading Australian suffrage campaigners such as Rose Scott, ${ }^{37}$ Muriel Matters ${ }^{38}$ and Vida Goldstein. ${ }^{39}$ But the images tend to be formal portraits, for example, of groups of women on delegations to the International Women's Suffrage Alliance in Rome in $1923^{40}$ or as delegates of the Australian Federation of Women Voters to the third triennial inter-state conference held in Melbourne. ${ }^{41}$ The different forms of the photographic images themselves influence the way in which the past can be reappropriated in the present. The plethora of material depicting fairly 'ordinary' activities, such as selling newspapers in London streets, helps develop a particular impression of the way the movement saw itself, creating a different use of the photographic genre to that of the formal studio portrait found in the Canberra archives. 


\section{Different Ideas of Creating Public History: British AND AUSTRALIAN Activists MaKING HISTORY}

The Suffragette Fellowship, founded in the 1920s by Edith How Martyn, a former WSPU member and WFL member, campaigned for equality between the sexes in political, educational and economic life. But its main function was to 'perpetuate the memory of the pioneers - connected with women's emancipation and especially with the suffrage campaign'. ${ }^{42}$ Its emphasis was upon the role of militant campaigners, particularly those in the WSPU and WFL. It initiated annual suffrage lectures, saluting the achievements of earlier 'pioneers' including Mary Wollstonecraft, which were then written up into short pamphlets. The Suffragette Fellowship took upon itself the role of public historian of the militant suffrage movement. It campaigned for different forms of public commemoration, such as a statue to Emmeline Pankhurst, and maintained and developed the collective memory of suffrage through a newsletter, Calling all Women. This publication continued to be produced until the 1960s, describing commemorative events and, with the passing of time, containing obituaries of former activists.

Most importantly the Suffragette Fellowship collected memorabilia, which the feminists described as 'relics'. They described their collection as 'the only authentic and unique collection of records and relics of the women's militant suffrage movement 19051914 ' ${ }^{43}$ In discussing the meaning of the term 'relics' museologist Susan Pearce has suggested that it implies 'lifeless debris... the dead shell of purposeful energy which has moved elsewhere... But to an earlier age "relic" meant the living dead at work amongst us, a voice from a past not left behind but entering into present life. ${ }^{44}$ For the Suffragette Fellowship their collection of past ephemera was an important part of present political and cultural life, leading them to seek wide audiences for its material. ${ }^{45}$

The successors of the NUWSS also sought, in different ways, to promote the history of the constitutionalists' role in the suffrage campaign. This included Ray Strachey's controversial book, The Cause, ${ }^{46}$ and support for a memorial service in Westminster Abbey to their leading figure, Millicent Fawcett, and a subsequent memorial to her in the Abbey. ${ }^{47}$ But its most famous contribution to the history of the feminist movement was the establishment in the 1920s of a library, which developed into the Fawcett Library, recently re-packaged as the Women's Library. The library, initiated by the London Society for Women's Service, ${ }^{48}$ had two objects: to 'provide a good working library on social, political and economic subjects for its members and to preserve the history of the women's movement in which the members themselves' had played an honourable part'. ${ }^{49}$ Over the decades the latter object became dominant with the increasing depositions of papers from former suffrage activists or their descendants, ${ }^{50}$ resulting in a collection fulsomely described by a former librarian as 'the largest and most comprehensive source of information on women in the United Kingdom, if not the 
world. ${ }^{, 51}$ The continued existence of such an archive has enabled, as Joanna Sassoon has discussed, 'material [that] can be woven into the garment of history'. ${ }^{2}$ Much of the academic interest, at least in British suffrage, can be attributed to the fascinating archives that the Women's Library possesses.

For its part the Suffragette Fellowship, having established its own archive and museum, offered the collection to the Museum of London in the 1940s. The collection was received enthusiastically. Although the curator responsible for the collection in the early 1950s did not have specific expertise in this field (being a medievalist by background) he was nevertheless enthusiastic about the collection, defining it as follows:

This collection of literature, propagandist material and relics of militancy and prison-life, diligently collected and cherished by these ladies, represents in a very complete fashion, every aspect, period and personality of the movement. ${ }^{53}$

As the feminists explained, their main object was to ensure that the collection 'shall not be scattered ${ }^{54}$ so that the history of the movement, as a movement, could be maintained. Encouraged by the museum curators, the Suffragette Fellowship members themselves carried out the initial cataloguing of the exhibits to ensure accuracy. Although they did not succeed in persuading the museum to devote a whole room to their collection, ${ }^{55}$ nevertheless when the suffrage section was opened the Suffragette Fellowship newsletter exclaimed, 'Years of loving, painstaking labour are now rewarded by the knowledge that the suffragette museum is henceforth a national possession. ${ }^{56}$ As public historians, collecting, preserving and displaying the material culture of the movement, the suffragettes created the conditions for their own historical memory and survival. The emphasis of these public historians of suffrage in establishing the Fawcett library or Suffragette Fellowship collections was upon the creation of particular group histories. And in this they succeeded: the Women's Library still exists and the suffrage displays at the Museum of London continue to be part of the permanent displays, irrespective of the re-fashioning of the galleries, so important and popular is the collection seen to be.

This form of creating public collections seems different to the Australian experience. Although keen to commemorate the work of individual women, the activists for the women's vote in Australia seem to have been less concerned with establishing a distinctive and collective perspective on their role in history. Certainly the Rose Scott Commemoration Fund sought to 'show their appreciation and regard for her and her work'. ${ }^{57}$ But this was a short-lived body, established to ensure a portrait was commissioned and presented to Rose Scott. It was agreed to commission John Longstaff, the artist also responsible for the portrait of Henry Lawson in the same gallery - whose portrait Rose Scott had previously admired $-{ }^{58}$ to paint her portrait for the Art 
Gallery of New South Wales in Sydney. The intention was 'to do her honour, and be a constant inspiration'. ${ }^{5}$

In similar fashion, on Vida Goldstein's death in 1949, the League of Women Voters of Victoria, under the presidency of Julia Rapke, established a fund specifically to honour her life and work. ${ }^{60}$ Some years later a portrait by Phyll Waterhouse was presented to the Library. ${ }^{61}$ An annual memorial essay prize was also inaugurated but foundered due to a poor response. ${ }^{62}$ Similarly, in Perth the Women's Services Guild of Western Australia commissioned a portrait by Daisy Rossi of Bessie Rischbieth to hang in its headquarters, presenting it to the Art Gallery of Western Australia in Perth in $1995 .{ }^{63}$

Such examples suggest that while individuals might be thought worthy of recognition there was no deliberate intention to create a collective history of women's franchise. The sterling efforts, however, of individual collectors such as Bessie Rischbieth in Western Australia and Ruby Rich in Sydney ensured both that their own material was deposited in archives and that others were encouraged to contribute their own memorabilia to the National Library of Australia (NLA). In her will of 1967 Rischbieth bequeathed her collection of papers, articles and photographs of the women's movement including material relating to 'the epic struggle of British women' to the NLA with the intention of ensuring that this material 'became the property of the Australian nation as national history'. ${ }^{64}$ Bessie Rischbieth had established a small museum in Perth, to which the Suffragette Fellowship added some depositions. It was then bequeathed to the NLA on her death in $1967 .^{65}$

The political links between British and Australian feminists are explicit through the display of material culture. Thus the NLA includes a cup and saucer, for example, presented to Bessie Rischbieth by the Suffragette Fellowship, similar in appearance to those in the Museum of London. Other bequests included personal items such as her OBE of 1935 and miniature self portrait hand painted by Cecile Upton in 1938. Clearly she possessed a strong sense of the importance of the past. She wrote a book, The March of Australian Women, sending a copy to Harold White, the NLA librarian, saying that she had had an amazing response although, 'Actually I did not think anyone would read it but I was determined to put the work on record'. ${ }^{66}$

The arrangement and use of her collection was to be left to the library. ${ }^{67}$ While this attitude might be read as an indication of her respect for the professionalism of the library staff, it might also suggest that she saw her role as organiser and accumulator rather than someone attempting to organise her extensive collection into a particular history. ${ }^{68}$ In 1953, together with Ruby Rich, she had visited the library with the proposal to establish a memorial to Vida Goldstein, which was positively supported by the librarian. ${ }^{69}$ In contrast, the files on the early decades of the Fawcett Library are full of 'hands-on' committee discussions about the appropriateness of items to be included in the collection. ${ }^{70}$ 
Ruby Rich had a long time association with the NLA, initiating an unsuccessful campaign to establish a separate women's centre within the library. In 1969 correspondence also ensued between Sir Kenneth Street and the National Library over the papers of his, by then very ill, wife Jessie. The librarian had sought the papers for some years, and reassured Kenneth that although Jessie had been incapable of sorting the papers due to her memory loss they would be happy to do so. ${ }^{71}$ In similar vein, Irene Greenwood, honorary life president of the Australian Federation of Women Voters, donated her papers to the Battye library in Perth in July 1978. ${ }^{72}$ In discussing the practice of individual collectors, Russell Belk has suggested that collecting can enlarge the collector's sense of self. ${ }^{73}$ But the depositions of individual collectors such as that of Bessie Rischbieth do more than this. While they might not provide a collective sense of participants' understanding - or not - of their historical role, by the materiality of their physical existence they provide material for present and future histories to be constructed. $^{74}$

Thus, it was due both to the initiatives of former suffrage activists themselves and the recognition of the importance of the collections by particular curators and archivists that the fine collections of suffrage material exist particularly in the Museum of London and the National Library in Canberra. ${ }^{75}$ But not all librarians were as enthusiastic as the National Library's Harold White or Graeme Powell.

Under the aegis of first librarian, Miss Pat Reynolds, apparently little attempt had been made at the La Trobe library in Melbourne to obtain documents from Victorian activists. ${ }^{76}$ Unsurprisingly, as the subsequent chief librarian C.A. McCallum wrote to librarian and academic Peter Biskup in 1958: 'Unfortunately not a great deal of information has been found since contemporary newspapers are almost the only source of information and there is very little indexing to cover the period in question. ${ }^{, 77}$

Subsequently Maya Tucker, writing in the La Trobe Library Journal, lamented the lack of material thus: 'Whatever happened to the papers of Harriet Dugdale, pioneer suffragette [sic] and feminist who lived in Melbourne, until her death in $1918 ?^{, 78}$ And still very little exists in this Victoria collection. Half a slim exercise book, a minute book of the Women's Franchise League of Ballarat including minutes of the first meeting in May 1894 deposited by J.K. Muir, ${ }^{79}$ is a sad document. This humble exercise book also contains sums, algebra and a child's drawing of a boat suggesting that it had not been regarded as an honoured document. ${ }^{80}$ Some material does now exist from Vida Goldstein but these are mere photocopies. ${ }^{81}$ Tellingly, the originals for the photocopies are deposited in the Women's Library in London. Edith How Martyn, both a founder of the Suffragette Fellowship and supporter of the Fawcett library, had donated many works that she had collected of the women's franchise campaigns both in Britain and Australia, where she had lived in the late 1940s. ${ }^{82}$ These had included material specifically donated to Edith How Martyn for the library by Vida Goldstein during her lifetime. On Goldstein's death, 
her sister, enacting Vida's wishes, donated other items. ${ }^{83}$ These materials include both her scrapbook of her visit to England but also cuttings of her Australian electoral campaigns and drafts of journals written in $1919 .{ }^{84}$ The photocopied material in Victoria suggests a later re-evaluation, rather than a contemporary acknowledgement, of the value of Goldstein's work. The specific intention that the originals be deposited in London perhaps also suggests a particular attempt by Goldstein to situate her own past in a collective history, which would have been - at the time - more sympathetic in valuing such contributions. ${ }^{85}$

\section{SOME QUestions OF DATES, Contexts AND Form}

So, if the practices of both individual collectors and institutions contributed to the creation of different types of collections in Australia and Britain, what other factors might have been significant in developing public histories of suffrage? Attitudes towards collecting or creating a collective memory of suffrage might stem, at least in part, from the inter-face of different personal and public chronologies. Ken Inglis' work on war memorials might be helpful here. Inglis noted that by 1900 - with the exception of representations of Queen Victoria - only twenty or thirty people, all men, were depicted on Australian statues. ${ }^{86}$ Given the imperial emphasis, women were scarcely considered worthy of commemoration for, Inglis continues, they 'were not governors or explorers or generals or colonial worthies... Even the one truly national heroine of England, Florence Nightingale, occupied no independent eminence. ${ }^{87}$

The context for memorials in the public landscape at a similar period in Britain was rather different. The tradition of public sculpture had already been established in the 1700 s and during the nineteenth century a range of figures were commemorated political, military, literary, industrial, philanthropic - as well as royalty. ${ }^{88}$ 'The pattern', as Benedict Read has argued, 'included national commemoration of national heroes, local commemoration of national heroes, local commemoration of local heroes... national artists doing national and local heroes, local artists doing national and local figures, let alone locally-born national artists executing local commemorations of national figures. ${ }^{, 89}$ In his analysis of the erection of public monuments in nineteenth-century Europe Serguisz Michalski has suggested that there was an increasing urge 'to commemorate important personage or patriotic events and memories acquired a new... dimension, moving beyond the limitations of individually conceived acts of homage'. Amongst widespread public sculpture, women were represented. Unsurprisingly, these female figures were overwhelmingly of royalty, although not confined to Queen Victoria. ${ }^{90}$ By the start of the twentieth century there was a tradition of public memorials that created a cultural context of potential public acknowledgement of people deemed important. In contrast in Australia, as Inglis remarks of the existence of monuments before the First World War, to 'people familiar with the public places of Europe, monuments of all sorts 
seem thin on the ground'. This absence, or emptiness, he suggests, 'signified a new society whose makers discerned few attainments worthy of commemoration'. ${ }^{91}$ This apparently collective 'modesty' was subsequently continued, I suggest, in the treatment of women's political role at this period. ${ }^{92}$

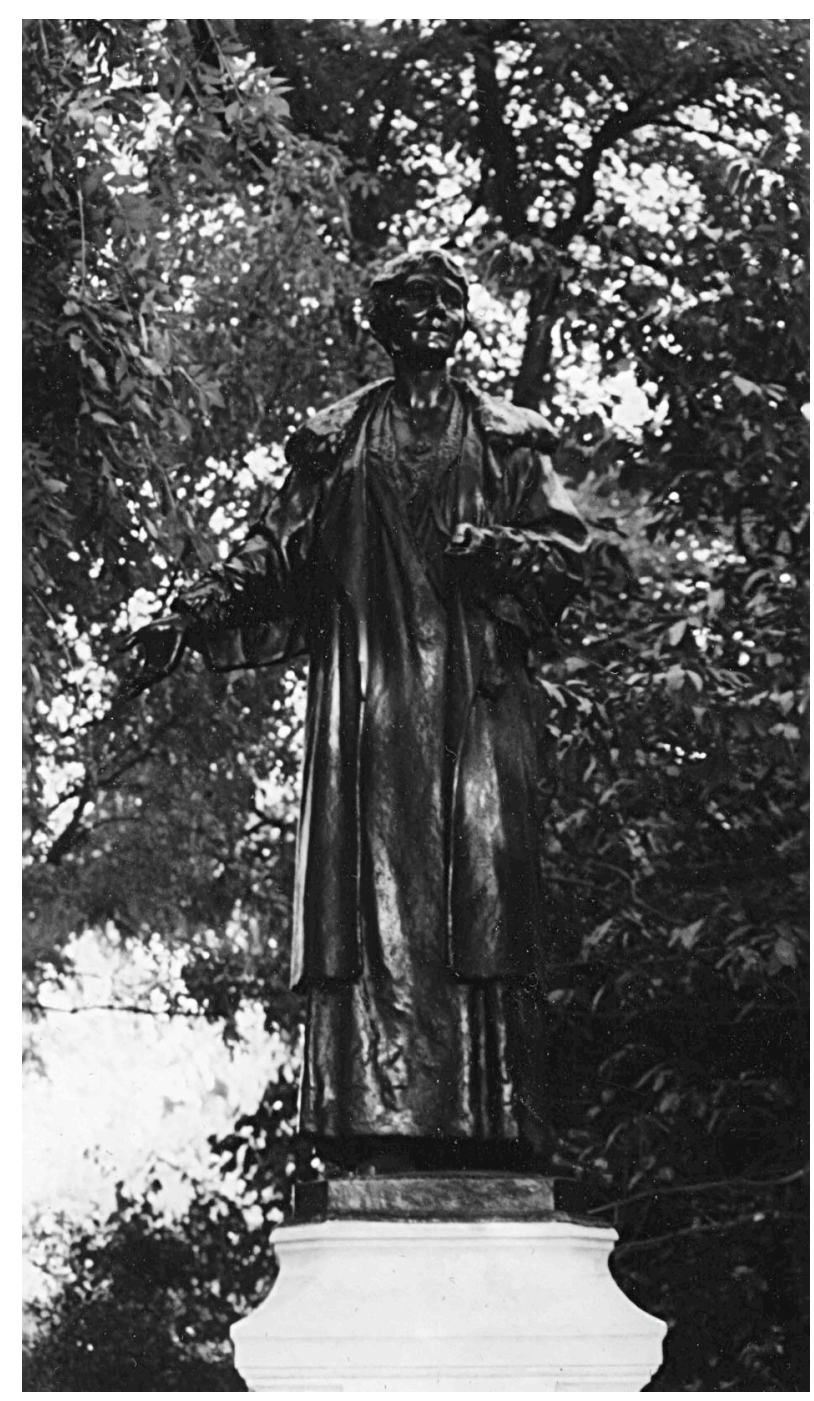

Statue of Emmeline Pankhurst by A.G. Walker, 1930, in Victoria Tower Gardens, London, adjacent to the Houses of Parliament (Photograph Hilda Kean)

In Britain, suffrage feminists sought to commemorate suffrage within the physical landscape through various initiatives. They realised that social space is not an empty arena within which we conduct our lives. Rather it is something we construct and which others construct about us. ${ }^{93}$ As Raphael Samuel argued, landscape is called upon to do 
the memory work that in earlier times might have been performed by 'territorial belonging'. ${ }^{94}$ Such public actions had included planting trees at the Blathwayt estate near Bath during the height of the pre-war militant campaign. Here a succession of released suffrage prisoners recuperated and individuals planted trees commemorating their own political activity for the suffrage cause. ${ }^{95}$ From the 1920 s onwards other forms of commemoration developed. Church pews, for example, were adorned with Mrs Pankhurst's initials in Chipping Ongar church in Essex. ${ }^{96}$ Former militants, including publisher Viscountess Rhondda, were responsible for raising funds for the erection of a statue to Emmeline Pankhurst in Victoria Tower Gardens, near the Houses of Parliament in London, and, after Christabel Pankhurst's death in the 1950s, a small relief of Christabel's profile in the same site. Their understanding of the importance of public commemoration was recognised by a memorial fund committee in a fund raising leaflet:

A statue is the recognised form of tribute paid to historic personalities, the highest and most lasting honour that humanity has ever been able to pay to those who have rendered great services to civilisation. As in ancient days, so now, men commemorate their heroes and liberators by erecting statues. Shall not women claim equal honour for her who led them to victory ${ }^{97}$

In due course, former suffragettes made regular pilgrimages to the site of Emmeline Pankhurst's statue on her birthday of 14 July and placed flowers in remembrance. ${ }^{98}$ Such public forms of commemoration emphasised the role of the Pankhurst family both due to their actual importance in the movement but also because of the actions the women had taken to develop particular 'histories' of their activity. ${ }^{99}$ There were also public forms of recognition in Australia, but the form tended to be different, and often took place some time after the individual had died. For example, through a public fund, a marble bust of Emma Miller, Queensland suffrage activist, was erected in the Trades Hall in Brisbane ${ }^{100}$ and Louisa Lawson was acknowledged in the naming of a block of Housing Commission flats in North Bondi, albeit not until 1952, some thirty years after her death. ${ }^{101}$ As Graeme Davison has suggested, 'while a statue may seem mute compared with a movie or a website it is also more fixed and durable. By its very solidity and permanence it is a quiet protest against all those other powerful, omnipresent but ephemeral forms of remembering. ${ }^{102}$ It might also be the case that a figurative statue in a public place presents a particular sense of historical memory that a mere naming does not convey, at least in the same way.

\section{London Blue Plaques and Australian Clocks}

Narratives in public sites can take many forms. ${ }^{103}$ As Margaret Anderson wrote in an article in an early issue of the Public History Review women had been written out of the 


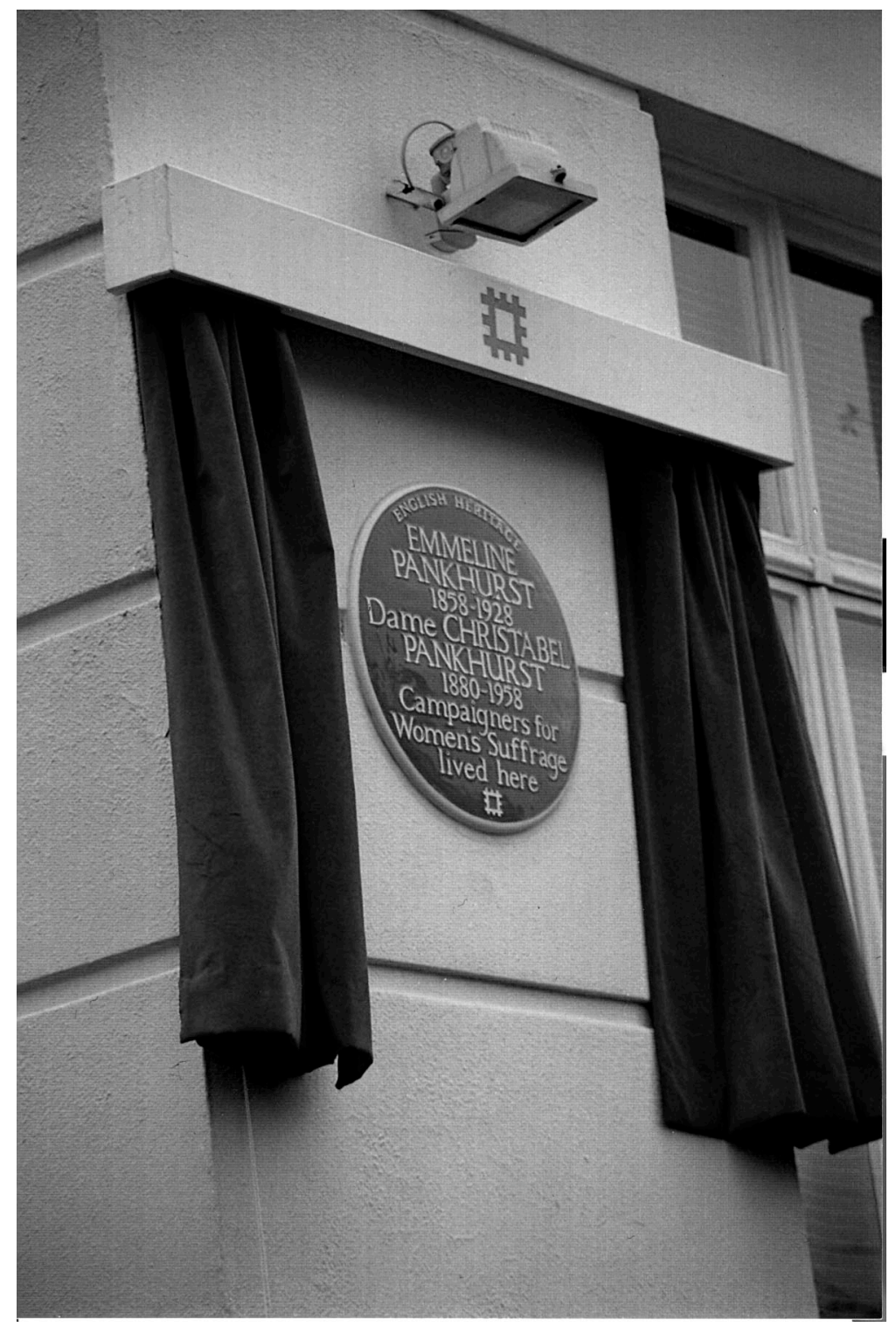

Blue Plaque to Emmeline and Christabel Pamkhurst, Notting Hill, London, unveiled February 2006 (Photograph Hilda Kean)

'general constructions of heritage'. ${ }^{104}$ She proposed that the homes of 'early suffragists' might be a starting point for presentation of activities in terms of gender. In considering this, Anderson seems to have been influenced by her knowledge that 'some of the houses in Bloomsbury in London now carry plaques identifying former residents of note, including leading feminist authors and suffrage campaigners'. ${ }^{105}$ This distinctive form and colour was originally a London form of memorialisation. ${ }^{106}$ The Royal Society of Arts had administered the blue plaques in the nineteenth century, the first being erected to 


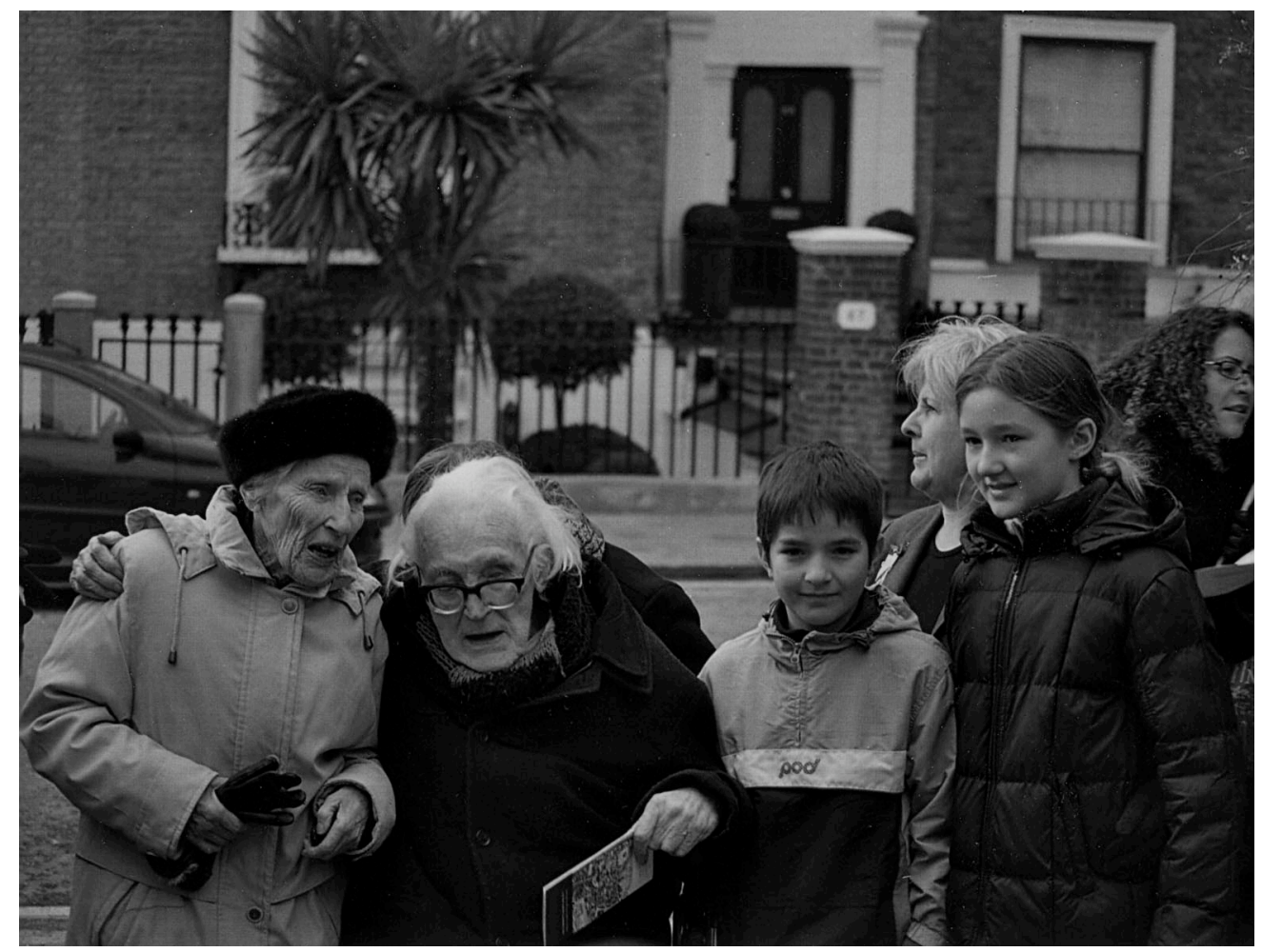

People at the unveiling ceremony of the Pankhursts' plaque including (from left) Eveline Bennett (an adopted daughter of Emmeline Pankhurst) former Labour Party leader Michael Foot, grandchildren of Sylvia Pankhurst and feminist historian Professor June Pervis (Photograph Hilda Kean)

commemorate the birthplace of Lord Byron. ${ }^{107}$ Decades before suffrage feminists' homes or the offices of the WSPU ${ }^{108}$ were marked with the status of a heritage plaque, female writers, scientists and actors had been already acknowledged. ${ }^{109}$

Therefore, in this form of memorial, as in public sculpture, feminists campaigning for the public role of suffrage activists to be acknowledged did not simultaneously need to argue for the form of representation. The validating of women's experience was tacked onto an earlier form in ways that were perhaps more difficult to enact in Australia.

The impact of the craze for World War I memorials and the creation of the digger motif as commemoration of a new nation in the 1920s and 1930s would provide the dominant discourse for Australian public memorials. ${ }^{110}$ As Barbara Caine has noted, the 1890s were celebrated some forty years later not as a period of agitation for female suffrage 'but as a decade of rising nationalism'. ${ }^{111}$ Within this period a striking statue in Sydney's botanical gardens could be erected (in 1930) to the dead Henry Lawson ${ }^{112}$ but not to his campaigning mother nor to other activists, who did not fit within the normative form of masculine nationhood. Edith Cowan, however, was publicly celebrated. The first woman to be elected to an Australian parliament as member for West Perth in the 


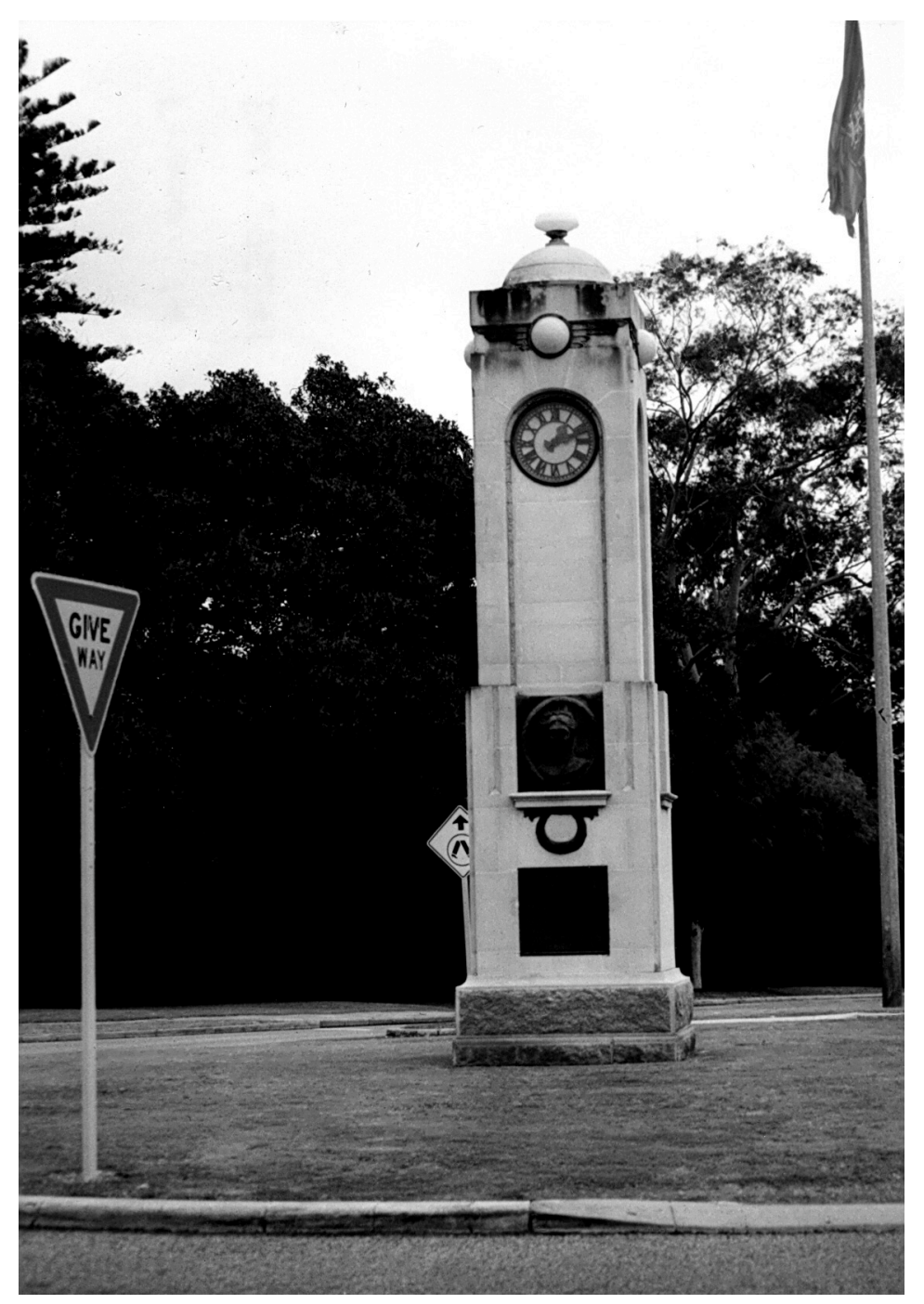

Clock tower to Edith Cowan outside King's Park, Perth (Photograph Hilda Kean)

Western Australia legislature, she was also the first British-born woman elected to a British Parliament. As such she was commemorated outside Perth's King's Park by a clock tower (now surrounded by road traffic). ${ }^{113}$ As Graeme Davison has described in his book The Unforgiving Minute public clocks had a particular place in the Australian public landscape. In the nineteenth century, the clock tower retained a lingering appeal as a symbol of authority and, even when public clocks were almost irrelevant to the timekeeping needs of most citizens, they maintained a particular status. ${ }^{114}$ It was this earlier form, which was used to honour Cowan - together with a small bust on the clock - rather than a statue or monument in the park itself, a place traditionally reserved for figures of a particular idea of national importance. 
The form of commemoration of women's involvement in suffrage campaigns was thus related to wider norms of forms of representation which were part of the respective cultures, during the decades after women received the vote. The dates of death of respective activists might also provide another particular context for forms of representation. It could be argued that in Australia many suffrage campaigners died before the First World War - before public commemoration was a norm. These included Mary Lee of South Australia who died in 1909 and Leontine Cooper of Queensland who died six years earlier. Other leading campaigners, including Henrietta Dugdale (1918), Louisa Lawson (1920), Rose Scott (1925) and Emma Miller (1917), would die in the period in which public commemoration was dominated by the impact of the World War I. These wider political contexts might help explain the lack of public acknowledgement at those particular moments.

The later dates of death of (some) leading British suffrage activists may have provided different contexts for forms of commemoration. Many were surprisingly long lived. They included Emmeline Pethick Lawrence (1867-1954) and Charlotte Despard (1844-1939) - both leaders of the Women's Freedom League; former WSPU members including Evelyn Sharp (1869-1955), Mary Richardson (1883-1961), Sylvia Pankhurst (1882-1960); and Viscountess Rhondda (1883-1957). Women such as these continued to be active in feminist politics in different ways after the vote was won. As a way of intervening in contemporary debates many chose to write autobiographies in which they considered the impact of the movement on their own sense of self. ${ }^{115}$ Conventionally, autobiographies are written as a reflection on a life largely already lived. As a representation of experience, rather than a quasi-objective historical account, autobiography became the genre through which suffrage feminists sought to appropriate and develop their previous political experience. Significantly 'external' time - the period of campaigning - rather than chronology relating to the years of an individual's life, provided the context for such writing.

Although these are ostensibly individual pieces of writing, there are common motifs in such works. These include the creation of a litany of martyrs - the 'pioneers' - and the establishment of a direct line of descent from previous feminist luminaries to the current members of feminist groups. Much of the writing reveals the same mythological and metaphorical devices identified by Passerini and Portelli in their work with veteran Communist militants, as I have discussed elsewhere. ${ }^{116}$ The suffrage autobiographical opus thus became almost a collective construction of the past. Through employing the genre of autobiography, rather than history, it was possible both to suggest the personal importance of a political movement and to convey the sense of changing life experiences that participation in suffrage was seen to convey. ${ }^{117}$ Tellingly, the emphasis on the 'personal' genre had provided much material for the creation of 'public' history. 


\section{RE-APPROPRIATINg SUfFRAge FOR THE PRESENT}

Despite the lack of thriving feminist movements in both contemporary Australia and Britain aspects of women's suffrage continue to be acknowledged (or ignored) in different ways in the present time. In both countries there has been 'official' recognition of the importance of women's suffrage. Activists have been acknowledged within the national biographical dictionaries, the Australian Dictionary of Biography ${ }^{118}$ and the New Oxford Dictionary of National Biography, ${ }^{119}$ in which the editors have made a successful attempt to include women's role in British society both through the subject matter and range of contributors. Historians of suffrage working inside and outside academia lobbied for particular activists to be recognised and subsequently wrote entries.

Recently a campaign bringing together feminist historians, trade unionists and socialists has mounted a tenacious campaign to erect a statue of Sylvia Pankhurst, the socialist, anti-fascist and anti-imperialist daughter of Emmeline, alongside that of her mother near the Houses of Parliament. To date, the location has proved controversial and planning permission has not been granted. ${ }^{120}$ In some ways, this campaign is an antidote to a popular understanding of suffrage which ignores the later politics of activists; it is also an intervention within certain academic debates about suffrage which promote separatist histories of women's lives. Outside the capital, many suffrage activists have been re-appropriated for the current period as characters within local histories. Popular, but often scholarly, publications have been produced outlining the activity of suffrage feminists in localities such as Liverpool, the North East, Cornwall, Hastings and Kent. That such works can be written indicates the material that exists as well as the way suffrage is used to give a particular 'cachet' to a locality and a place within national politics. In similar vein, plaques have been erected and roads named after activists, including a recent addition near the Epsom racecourse where Emily Wilding Davison fell under the king's horse in $1913 .{ }^{121}$

In Australia, greater attention seems to have been paid to celebrating suffrage centenaries. ${ }^{122}$ This has included the commemorative coin to Mary Lee and a statue to her created in Adelaide's Prince Henry Gardens in 1994 on the centenary of the first state to give women the vote in December 1894. In Sydney the Jessie Street memorial park was dedicated to the 'great women' of Australia. ${ }^{123}$ To celebrate the centenary of white women receiving the vote in Western Australia, the part of King's Park gardens around the Pioneer Women Memorial (with symbolic water spray) were refurbished. ${ }^{124} \mathrm{~A}$ women's suffrage pavilion was created, built by carpentry and joinery apprentices at West Coast college of Technical and Further Education. Nearby are sculptures of sheets of Hansard inscribed with nineteenth century debates. ${ }^{125}$ The celebrations also established a women's walk with plaques naming a range of women's organisations including the Women's Christian Temperance Union of Western Australia, the National 


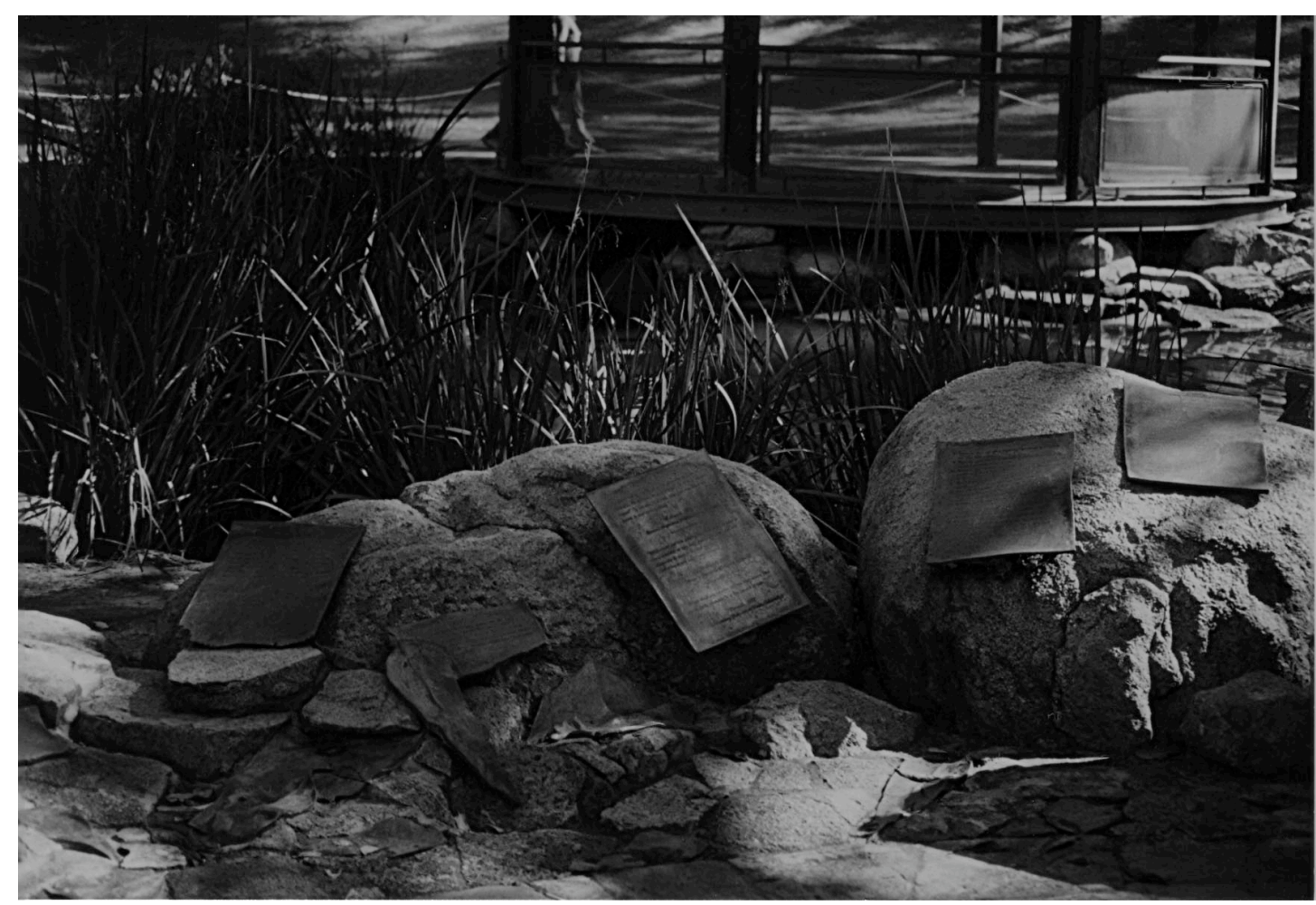

Artwork with pages from Hansard outside the women's suffrage pavilion, King's Park, Perth (Photograph Hilda Kean)

Council of Women, the Women's International League for Peace and Freedom, the Karrakatta Club and the Australian Federation of University Women.

But it is not a simple task to re/create suffrage history for the present. Several historians have discussed the difficulties of apparently celebrating a centenary for the women's vote in Australia since this might appear to legitimise the exclusion of Aboriginal women (and men). The politics of the present have problematised the past, showing that any easy celebration of 'the past' is neither possible nor desirable. While Patricia Crawford and Judy Skene edited a special edition of Studies in Western Australian History to commemorate the event, nevertheless they described the 1999 celebrations as an 'ambiguous centenary'. ${ }^{126}$ The relationship between materials of the past and current histories has also raised issues in museum practice.

At the National Portrait Gallery in London, for example, attempts have been made to give greater weight to the importance of women's suffrage. Temporary exhibitions including suffrage photographs, the permanent display of Emmeline Pankhurst's portrait, inclusion of material on the onsite website and postcards of Pankhurst's painting on sale in the shop are valuable. However, they cannot but reveal the former collecting policies that paid scant attention to the acquisition of suffrage materials. The relative paucity of 
materials collected in the past makes it difficult to create current exhibitions from inhouse materials.

Museums are not privileged places: the people who work in them are part of social practice in a social world. ${ }^{127}$ Thus the influence of cultural relativism has had a particular impact on the portrayal of suffrage, particularly the Australian campaign for example, as covered at the National Museum of Australia (NMA) in Canberra. Curatorial policy sought to create a museum that questioned previous historical assumptions especially around the formation of nation and the depiction of indigenous peoples. ${ }^{128}$ Although visitors might have known much of the subject matter of the NMA, the perspective was intended to be new. Within the collection, women's political role is acknowledged. A story of Emma Miller, President of the Women's Equal Franchise Association of Queensland, for example, is included in the section 'Eternity, Stories from the emotional heart of Australia' and Mary Lee's 1994 commemorative coin is also on display. Such narratives compete, however, with the little leather boots made for Myles Dunphy's dog, or a rotary clothesline, for the attention of visitors. Thus, while ephemera depicting suffrage is on display, suffrage is not necessarily the focus of the presentation. Simultaneously, the suffrage movement is being lauded and devalued though its juxtaposition with the mundane. In similar fashion while Bessie Rischbieth's portrait by Daisy Rossi is on display in the Art gallery of Western Australia, the gallery leaflet emphasises the role of the artist rather than the important political work of the sitter.

A task historians face is to 'address not only the record of the past but also the hidden forces shaping contemporary understandings of it, the imaginative complexes in and through which it is perceived'. ${ }^{129}$ Attempts to bring suffrage into the present are, unsurprisingly, complex and contradictory. In discussing the relationship between the past and the present Walter Benjamin was acutely aware of the need for each generation to fight anew for its history: 'To articulate the past historically does not mean to recognize it "the way it really was" (Ranke)'. A history of the past needs to be fought for anew in every generation, the past being brought into the present if the past is not to disappear. ${ }^{130}$ While the new National Portrait Gallery established in Canberra in 1998 can proudly display a portrait of Catherine Spence, the Art Gallery of New South Wales no longer has the John Longstaff portrait of Rose Scott on permanent display. ${ }^{131}$ But the example of Louisa Lawson tells a different story.

Writing in 1978, Lorna Ollif had noted that while Louisa Lawson had been one of six Australian women to feature on ten cent stamps in International Women's Year, nevertheless her burial place in the family grave in Rookwood cemetery was 'overgrown with weeds' and 'No women's libbers [sic] make a pilgrimage to it. ${ }^{132}$ By 1989, however, the resting place of Louisa was being reclaimed, not by explicitly latter day feminists but by the genealogists and public historians of Rookwood Necropolis cemetery. In their 
compilation of the 'famous and the unknown' Louisa received pride of place as a renowned 'suffragette' and 'newspaper proprietor'. ${ }^{133}$

In thinking about the relationship between the past and the present we might also need to view the present 'historically' and consider what might be collected for future histories. A pertinent example might be the mile long banner created for the suffrage centenary celebrations in Western Australia. The actual banner, a mere eight years on, no longer exists. Storage proved a problem and now only a replica, preserved as visual images on a CD, exists. As the organisers ruefully described it, the original banner 'was not preserved and is now but a footnote in an ever dwindling number of texts'. ${ }^{134}$

An exploration of different approaches to the creation of histories of women's suffrage might help us to raise questions about the relationship between material culture and present understandings or pursue issues about the nature of creating collective histories and the role of individuals in that process. It might also prompt us to look too at the 'everyday' - or different - cultures in critical ways. As Tom Waits put it more elegantly in one of his songs, 'subsequently bear in mind your transient position/allows you a perceptive that's unique'.

\section{ENDNOTES}

1 Thanks to June Hannam, Katherine Bradley and PHR reviewers for their helpful comments on earlier drafts; to Joanna Sassoon and Anne and Tom Marshall for drawing my attention to particular materials in Perth and to librarians and archivists at the National Library in Canberra, Women's Library, London, Museum of London, Mitchell Library, Sydney, City of Sydney Archive, La Trobe Library, Melbourne and Battye Library, Perth.

2 For example, Dora Montefiore, a leading British suffrage militant and activist in the Social Democratic Federation, had been the honorary secretary of the Womanhood Suffrage League of New South Wales in its earliest days. Australian Muriel Matters had dedicated herself to spectacular acts in London, flying in a hot air balloon over the Thames and chaining herself to the grille in the House of Commons Ladies Gallery. Having been invited to Britain by the WSPU, the leading militant organisation in 1911, Victoria activist Vida Goldstein used her Australian experiences in the British women's cause. Visiting WSPU meetings in 1913, Western Australian Bessie Rischbieth described her impression of Emmeline Pankhurst, leader of the organisation, thus: 'really as I listed I felt my backbone growing longer as though you gained courage and freedom from her.' There were also ties of friendship and family between activists, Sydney's Jessie Street, for example, being the cousin of Winifred Mayo of the WSPU, a founder of the Actresses Franchise League and a subsequent organiser of the Suffragette Fellowship. Karen Hunt, 'Journeying through suffrage: the politics of Dora Montefiore', in Claire Eustance, Joan Ryan and Laura Ugolini (eds), A Suffrage Reader: Charting Directions in British Suffrage History, Leicester University Press, 2000, pp162-76; Hilary Frances, 'The Women's Freedom League and its legacy', in Purvis and Holton, Votes for Women, p189; Vida Goldstein, 'A record of my visit to England in 1911'; Scrapbook donated after her death to Edith How Martyn at Goldstein's request. Vida Goldstein Cuttings files, Women's Library, London; Bessie Rischbieth to her sister Olive Evans 18 July 1913 Rischbieth papers, MS 2004/1/12 National Library of Australia as quoted in Dianne Davidson, 'A citizen of Australia and the world: A reappraisal of Bessie Mabel Rischbieth', in Patricia Crawford and Judy Skene (eds), Women and Citizenship: Suffrage Centenary, special issue of Studies in Western Australian History, vol 19,1999, pp99-113, p103.

3 Vida Goldstein attributed the first campaigns to Henrietta Dugdale speaking and writing on the issue in 1869. The first organisation in Victoria, the Women's Franchise League was founded by Dugdale, Mrs Smythe and Mrs Lowe in 1884. Vida Goldstein, Woman Suffrage in Australia, Women's Press, nd, p1.

4 Rita Farrel, 'Women and citizenship in colonial Australia', in Patricia Crawford and Philippa Maddern (eds), Women as Australian Citizens: Underlying Histories, Melbourne University Press, Melbourne, 2001, pp115- 40; 138.

5 Patricia Grimshaw, Marilyn Lake, Ann McGrath and Marion Quartly, Creating a Nation 1788-1990, Penguin Australia, Melbourne, 1994, p185.

6 Farrel, 'Women and citizenship', in Colonial Australia, p138. 
7 Mary Davis, Comrade or Brother? The History of the British Labour Movement 1789-1951, Pluto Press, London, 1993, p56.

8 Constance Rover, Women's Suffrage and Party Politics in Britain 1866-1914, Routledge and Kegan Paul, London, 1967, p218.

9 Judith Walkowitz, Prostitution and the Victorian State, Cambridge University Press, 1982, pp113-36.

10 Rover, Women's Suffrage, p29.

11 The vote was achieved in 1928 due to ongoing campaigns during the 1920s. See Cheryl Law, Suffrage and Power: The Women's Movement, 1918-1928, I B Tauris, London, 2000. For a comprehensive account of the different legislation see Rover, Women's Suffrage and Party Politics in Britain 1866-1914.

12 Sandra Stanley Holton, Suffrage Days Stories from the Women's Suffrage Movement, Routledge, 1996, p100.

13 See for example, Ann Morley with Liz Stanley, The life and times of Emily Wilding Davison, Women's Press, 1988; Lisa Tickner, The Spectacle of Women: Imagery of the Suffrage Campaign 1907-14, Chatto and Windus, London, 1987; Hilda Kean, Deeds not Words: The Lives of Suffragette Teachers, Pluto Press, London, 1990.

14 See for example Barbara Caine, 'Vida Goldstein and the English militant campaign', Women's History Review vol 2, no 3, 1993, pp363-76; Ann Nugent, 'Sister Suffragists: Australian women activists in England', National Library of Australia News, vol X111, no 5, Feb 2003; Jennie Baines, 'Suffrage and an Australian connection', in June Purvis and Sandra Stanley Holton (eds), Votes for Women, Routledge, 2000, pp246-66.

15 In their introduction to Votes for Women, June Purvis and Sandra Stanley Holton devote four pages of footnotes to outlining recent work on the British suffrage movement, pp7-10.

16 www.links4kids.co.,uk/top100britons.htm accessed 22 September 2003.

17 Hilda Kean, 'Public History and Popular Memory: Issues in the commemoration of the British militant suffrage campaign, Women's History Review, vol 14, no 3, 2005, pp585-606.

18 Ruth Teale (ed), Colonial Eve: Sources on women in Australia 1788-1914, Oxford University Press, Melbourne, 1978, p253.

19 Anne Summers, Damned Whores and God's Police: The colonization of Women in Australia, Penguin, Ringwood, Victoria, 1975, p359.

20 Marilyn Lake, Getting Equal: The History of Australian Feminism, Allen and Unwin, Sydney, 1999, pp19-44.

21 Stuart Macintyre, A Concise History of Australia, Cambridge University Press, Melbourne, 1999, p134-6.

22 Jill Roe, 'Chivalry and social policy in the Antipodes', in Richard White and Penny Russell (eds), Memories and Dreams: Reflections on Twentieth-Century Australia, Allen and Unwin, Sydney, 1997, p5.

23 Audrey Oldfield, Woman Suffrage in Australia: A gift or a struggle? Cambridge University Press, Melbourne, 1992.

24 Barbara Caine, Australian Feminism: A Companion, Oxford University Press, Melbourne, 1998.

25 Although reference is made, for example, to Mary Lee's commemorative coin and Bessie Rischbeith's portrait: Caine, Australian Feminism, pp448-9; 483.

26 See Hilda Kean, 'Mary Richardson', New Oxford Dictionary of National Biography, Oxford University Press, Oxford, 2004 (www.oupcom/oxforddnb/info/).

27 Emmeline Pankhurst died before the election was called. Paula Bartley, Emmeline Pankhurst, Routledge, London, 2002, p221.

28 Emmeline Pankhurst had been a leading member of the Independent Labour Party; ibid, pp44-67.

29 Hilda Kean, 'Public History and Popular Memory', Women's History Review, vol 14, no 3, 2005, pp588-9.

30 Henry Salt, Shelley Poet and Pioneer: A Biographical Study, W. Reeves, London, 1896, p18; Henry Salt, Percy Bysshe Shelley: A Monograph, Swan Sonnenschein, London, 1892, p45-7; Paul Foot, Red Shelley, Sidgwick and Jackson, London, 1984, pp244-6; lan Haywood, The Literature of Struggle: An Anthology of Chartist Fiction, Scolar Press, Aldershot, 1995; Timothy Randall, 'Chartist Poetry and Song', in Owen Ashton, Robert Fyson and Stephen Roberts (eds), The Chartist Legacy, Merlin Press, Suffolk, 1995, pp171-195; Yvonne Kapp, Eleanor Marx, Lawrence and Wishart, London, 1976, vol 2, p250; Appendix 2 in Kapp, Eleanor Marx, vol 2, pp735-6; Bouthaina Shaaban, 'Shelley and the Chartists', in Betty T. Bennett and Stuart Curran (eds), Shelley Poet and Legislator of the World, John Hopkins University Press, Baltimore, 1996; Andrew Elfenbein, Byron and the Victorians, Cambridge University Press, Cambridge, 1995, p85-7.

31 Goldstein, Woman Suffrage in Australia, p2.

32 Vicki Crowley, 'Acts of memory and imagination: reflections on women's suffrage and the centenary celebrations of suffrage in South Australia in 1994', Australian Feminist Studies, vol 16, no 35, 2001, p234.

33 For example, the WCTU deputation to Munro the temperance premier of Victoria in 1891: Oldfield, Woman Suffrage in Australia, p139.

34 For example, the Womanhood Suffrage League in New South Wales: Oldfield, Woman Suffrage, pp81-2.

35 Rose Scott on the 1902 act as quoted in Grimshaw et al, Creating a Nation, p185.

36 Tickner, The Spectacle of Women; Diane Atkinson, The Suffragettes in Pictures, Museum of London, 1996; Diane Atkinson, Mrs Broom's Suffragette photographs, Nishen Photography, nd.

37 National Library of Australia, MS2004/4/72.

38 National Library of Australia, MS 2001/3/278. 
39 National Library of Australia, MS 2006/4/218.

$40 \quad$ National Library of Australia, plate NL2657.

41 National Library of Australia, nd, plate 23639.

42 Objects of the Suffragette Fellowship as printed in Thelma Cazalet Keir MP, I knew Mrs Pankhurst, Suffragette Fellowship, nd.

43 Draft text of the label which the Suffragette Fellowship requested the Museum of London to affix to the collection on transfer. Undated letter (November 1950?) from Una Duval to Mr Grimes, Objects relating to the Suffragette movement Museum of London Acc 50.82 (1-1549).

44 Susan M. Pearce, Museums, Objects and Collections: A Cultural Study, Leicester University Press, 1992, p197.

45 For its part the Women's Freedom League campaigned, unsuccessfully, for the National Portrait Gallery to hang portraits of its leaders during the suffrage campaign, Charlotte Despard and Emmeline Pethick Lawrence, alongside the portrait it possessed of Emmeline Pankhurst . Minutes of Women's Freedom League National executive committee, 13 July 1935, in box 55 WFL collection, Women's Library.

46 This was a history of the suffrage campaign from the 'Constitutionalist' perspective including a controversial chapter criticising the tactics of the militants. The WFL demanded, unsuccessfully, that the offending chapter be re-written and copies removed from the British Library. Minutes of Women's Freedom League National executive committee, 25 January 1929, in box 55 WFL collection, Women's Library.

47 This was the first time a memorial service - 19 November 1929 - had been held for a woman in Westminster Abbey; and the first time a memorial was erected to both a husband and wife in the Abbey. Fawcett Library scrapbook no 47: Millicent Fawcett's death, Women's Library.

48 This was the first of the women's suffrage societies with its origins in the $1860 \mathrm{~s}$

49 Vera Douie, The Foundation and Building up of the Fawcett Library. Talk given to Friends of Fawcett library at the City of London Polytechnic, 21 January 1978, photocopy, Women's Library, p2.

50 See, for example, deposition of albums of designs for suffrage banners by Mary Lowndes presented in 1951 or the papers of the late Teresa Billington Greig deposited by her daughter. Fawcett library (annual) report, March 1951-February 1952; Library (quarterly) committee minutes, 9 December 1964, Women's Library.

51 Alan Pritchard and David Doughan, 'Access to the Literature on Women. The Fawcett library and Bilbiofem', Assistant Librarian, vol 72, no 2, February 1979, p22.

52 Joanna Sassoon, 'Phantoms of remembrance: Libraries and archives as the "collective memory"', Public History Review, vol 10, 2003, p55. See also Carolyn Steedman, Dust, Manchester University Press, 2001.

53 Letter of Mr Spencer, curator at the Museum of London to Mr Jogden, Corporation Museum, Keighley, 11 February 1954, Acc 50.82, Museum of London.

54 Letter of Winifred Mayo to Mr Grimes, 3 Mary 1948, 'Objects relating to the suffragette movement', Acc 50.82, Museum of London.

55 Correspondence in 'Objects relating to the suffragette movement', Museum of London, Acc 50.82. Although the Museum was unable to accept the conditions, nevertheless a suffrage exhibition has been a constant feature of gallery displays and is highly likely to continue to do so in the museum's new re-organisation.

56 Calling all Women, February 1952, p3 in 'Objects relating to the suffragette movement', Acc 50.82, Museum of London.

57 Letter from Women's Club, 77 Kings St, Sydney, 11 February 1921 from Mary Booth to Miss Windeyer, in Rose Scott Commemoration Fund file ML MSS 6893 1(1) Rose Scott Archive, Mitchell Library.

58 Rose Scott's speech on the unveiling of her portrait by Lady Forster 24 September 1922 As 75/3, Mitchell Library.

59 Letter from Rose Scott Commemoration Fund to Miss Windeyer, 9 March 1921, in Rose Scott Commemoration Fund, file ML MSS 6893 1(1), Rose Scott Archive, Mitchell Library.

60 Vida Goldstein acquisition of material and memorial, 203/07/00070 Memo, 3 August 1983, from Catherine Santamaria, Director Australian Studies, National Library of Australia.

61 The Age, Melbourne, 27 July 1973, p21; File 61/13/85, National Library of Australia, Canberra.

62 Leslie Henderson, Vida Goldstein 1869-1949, Box 332/14 MS 7930, State Library, Melbourne, Victoria.

63 Caine, Australian Feminism, p483 and leaflets in Western Art Gallery, Perth, 2004.

64 Presents to Mrs Rischbieth, no 94, dated 17 March 1967, 206/19/00022, National Library of Australia.

65 Calling all Women, July 1960, p5.

66 Letter from Bessie Rischbieth to Mr White, 18 February 1965, 206/19/00022, no 77, National Library of Australia.

67 File note by Harold White, 24 January 1955, in 206/19/00022 National Library of Australia.

68 See Russell W. Belk, Collecting in a Consumer Society, Routledge, 1995, pp67-8 for a discussion on accumulation and collection.

69 Vida Goldstein acquisition of material and memorial 203/07/00070, National Library of Australia

70 Fawcett Library minutes, 2/LSW/L/2 box 392, Women's Library, London.

71 NLA acquisition file Jessie Mary Grey Street (New South Wales) letters from Harold White 19 September 1969; Kenneth Street, 3 September 1969; 203/19/00125 National Library of Australia.

72 MN 826 Acc 2765A, Battye Library, State Library of Western Australia. 
${ }^{73}$ Belk, Collecting in a Consumer Society, p89.

74 See, for example, Roy Rosenzweig and David Thelen, The Presence of the Past Popular Uses of History in American Life, Columbia University Press, New York, 1998.

75 The depositions from Ruby Rich are due to the active work of the current curator of Manuscripts, Graeme Powell, seeking to obtain her papers when she died. Conversation with author 15 July 2004; Ruby Rich, latest proposal, memo from Catherine Santamaria, Director Australian Studies, 3 August 1983, 203/07/00070. Former librarian Harold White also recognised the value of Mrs Rischbieth's collections, ensuring material was deposited in the National Library, while not acceding to her request for a separate department for women's materials within the library. Ruby Rich, latest proposal, memo from Catherine Santamaria, Director Australian Studies, 3 August 1983, 203/07/00070 National Library of Australia.

76 Pers com with current curator, July 2004.

77 Biskup had sought information about the Women's Suffrage Society. Letter from C. A. McCallum to Peter Biskup, Suffrage Women's File, La Trobe Library.

78 Maya V. Tucker, 'Sources on Australian Women 1880-1914, available at the La Trobe Library', La Trobe library journal, vol 4, no 15, April 1975, p61.

79 There appears to be no information on the circumstances of deposition. Jennifer Feeney, 'Votes for Women the Women's Franchise League of Ballarat', La Trobe Library Journal, vol 8, no 31, April 1983.

80 J. K. Muir collection, Box 60; 'Women's Franchise League of Ballarat'.

81 For example MS11956, Box 2493/5. Indeed the main work around Goldstein is not by her at all but a typed and privately bound work of fifteen pages written by her niece in January 1966, some seventeen years after her death. (Box 332/14 MS 7930, Leslie M. Henderson.)

82 Hilary Frances, 'Edith How Martyn', New Dictionary of National Biography, vol 37, 2004, pp32-3.

83 Documents donated to Edith How Martyn for the Women's Service Library during Vida Goldstein's lifetime, according to inscriptions on front sheet of booklets: Press Cuttings/scrapbook of Australian election campaigns and related material, VDG10 and VG9, 'A diary of cuttings for 1908' (VG4); other material deposited after her death included an autograph book (VD/2) and a record of Goldstein's visit to England in 1911 (VG5) Women's Library.

84 Journal of 1919 from Melbourne to London, Switzerland and Paris; Sidelights on Peace, Journal London JulyOctober 1919 (VDG and VD7). These contain withering prefaced comments by Edith How Martyn: 'I have managed to finish this [Sidelights] and find it well ill-balanced, prejudiced, unchristian... unhistorical... But you have judged for yourself'. Women's Library.

85 This is suggested both by inscriptions in the depositions and through conversations with Gail Cameron, librarian at the Women's Library, August 2005.

86 K. S. Inglis, Sacred Places: War memorials in the Australian Landscape, Miegunyan Press, Melbourne University Press, Melbourne, 1999, p26.

87 ibid, p30

88 Benedict Read, Victorian Sculpture, Paul Mellon Centre for Studies in British Art, Yale University Press, 1982, p85.

89 ibid.

90 These included in London alone, the Eleanor Cross (Charing Cross) 1863, statues in Houses of Parliament and Boadicea (Embankment) Read Victorian Sculpture.

91 Inglis, Sacred Places, p72.

92 It was not unusual in Australia for time to pass before a monument was erected. The monument to New South Wales's first governor, Captain Arthur Phillip, was not erected in Sydney until 1897 some years after his death. Even then his convict origins were obscured. See Paul Ashton, 'The past in the present: Public history and the City of Sydney', in Tim Murray (ed), Exploring the modern city: Recent Approaches to urban history and archaeology, Historic Houses Trust, NSW and La Trobe University, Sydney, 2003, p6.

93 Doreen Massey, 'Space-Time and the Politics of Location', in James Lingwood (ed), Rachel Whiteread, House, Phaidon Press, 1994, p36.

94 Raphael Samuel, Theatres of Memory, Verso Press, London, 1994, p39.

95 B. M. Wilmot Dobbie, A Nest of Suffragettes in Somerset, Batheaston Society, 1979.

96 Paula Bartley, Emmeline Pankhurst, p230; Mary Hayter, 'The Cry of the Strenuous: Jessie Stephenson', unpublished MA, Public History dissertation, Ruskin College, Oxford, 2004.

97 The Mrs Pankhurst Memorial, fund raising leaflet, Memorial Material SC 35, Women's Suffrage collection, Museum of London.

98 Calling all Women, July 1960. They also made annual pilgrimages to Morpeth in the North East of England where Emily Wilding Davison was buried.

99 This included the ghosted autobiography of Emmeline Pankhurst, My Own Story, Eveleigh Nash, London, 1914; Christabel Pankhurst's posthumously published, Unshackled: The Story of How we Won the Vote, Hutchinson, London, 1959 and Sylvia Pankhurst's influential The Suffragette Movement, an intimate account of persons and ideals, London, Virago, first published 1931. 
100 Australian Dictionary of Biography, vol 10, p510.

101 Australian Dictionary of Biography, vol 10, p25.

102 Graeme Davison, The Use and Abuse of Australian History, Allen and Unwin, St Leonards, 2000,p55

103 Daniel Walkowitz and Lisa Maya Knauer (eds), Memory and the impact of political transformation in public spaces, Duke University Press, 2004, p9.

104 Margaret Anderson, 'In search of women's public history: History and gender', Public History Review, vol 2, 1993, p3.

105 ibid, p8.

${ }^{106}$ Plaques do exist in other towns and cities but not usually in blue. In recent years English heritage has taken over this role of erecting plaques in London.

${ }_{107}$ Ben Weinreb and Christopher Hibbert (eds), The London Encyclopaedia, Book Club Associates, 1983, p76.

108 A plaque was unveiled on the site of the WSPU offices in 4 Clements Inn in 1960. At a similar time a plaque was unveiled in the Free Trade Hall Manchester to commemorate the first act of militancy of the WSPU in 1905. Calling all Women, July 1960, p3.

109 Plaques included those to: Joanna Baillie dramatist late eighteenth and early nineteenth century, Hampstead erected 1900 ; Elizabeth Barrett Browning, Wimpole Street 1924 ; Fanny Burney, Bolton St W1 1885; George Eliot, Wimbledon Park Road 1905; Elizabeth Gaskell, Cheyne Walk 1913; Jenny Lind 1909; Sarah Siddons, Baker Street 1876; Mary Somerville, scientific writer, Hanover Square 1909. See Victor Burrows (ed), The Blue Plaque Guide, Newman Neame, London, 1953.

110 Inglis, Sacred Places, p123.

111 Elizabeth Webby, 'Gender, representation and national identity', in Caine, Australian Feminism, p117.

112 Manning Clark, Henry Lawson The man and the legend, Sun books, Australia, 1985, p168; Brian Matthews, Pursuing Literature and History in Australia: the fate of Henry Lawson and Manning Clark, The Menzies Memorial Lecture, Sir Robert Menzies Centre for Australian Studies, University of London, 1996.

113 Paul Wycherley, Mrs Cowan's clock: The location of the Edith Cowan Memorial, Edith Cowman University WA. There was a re-dedication ceremony in March 1996 on the 75th anniversary of her election to the legislative assembly and then a touring exhibition of her life, 'A tough nut to crack'. A conference was held celebrating women in public life and a collection of her edited speeches was published. See Harry C. J. Phillips, The Voice of Edith Cowan, Australia's First Woman Parliamentarian 1921-1974, Edith Cowan University, 1996, preface.

114 Graeme Davison, The Unforgiving Minute: How Australia Learned to tell the time, Oxford University Press, Melbourne, 1993, pp35; 40-1.

115 Antony Giddens, Modernity and Self Identity, p52-4 quoted in Carolyn Steedman, 'Enforced narratives: Stories of another self', in Tess Coslett, Celia Lury and Penny Summerfield (eds), Feminism and Autobiography: Texts, Themes, Methods, Routledge, London, 2000, p26.

${ }^{116}$ Hilda Kean, 'Searching for the past in present defeat: the construction of historical and political identity in British feminism in the 1920s and 1930s', Women's History Review, vol 3, no1, 1994, pp57-80; Hilda Kean,'Some Problems of Constructing and Reconstructing a Suffragette's Life: Mary Richardson; Suffragette, Socialist and Fascist', Women's History Review, vol 7, no 4, 1998, pp475-94.

117 Examples of suffrage autobiography include Cicely Hale, A Good long time: The autobiography of an octagenarian, Regency Press, London, 1973; Mary Richardson, Laugh a Defiance, Weidenfeld and Nicolson, London, 1953; Margaret and Mary Thompson, They Couldn't Stop us! Experiences of Two (Usually Law-Abiding) Women in the years 1900-1913, Harrison, London, 1957; Mary Gawthorpe, Uphill to Holloway, Traversity Press, Maine, 1962; Emmeline Pethick Lawrence, My Part in a Changing World, Victor Gollancz, London, 1938; Viscountess Rhondda, This was my World, Macmillan, London, 1933; Cicely Hamilton, Life Errant, Dent, London, 1932.

118 Australian Dictionary of Biography, Melbourne University Press, 1986.

119 www.oupcom.oxforddnb/info.

120 See website of the Sylvia Pankhurst memorial committee, www.gn.apc.org/sylviapankhurst

121 Kean, 'Public History and Popular Memory', pp595; 605.

122 A commemorative coin portraying Mary Lee was issued in Australia in 1994. See Caine, Australian Feminism, pp448-9.

${ }^{123}$ Simon Cameron, Silent Witnesses, Adelaide's statues and monuments, 1997, p150; Louella McCarthy and Paul Ashton (eds), Sydney Open Museum History Survey, Sydney City Council, Sydney, 1994, pp76; 79.

124 Women's Suffrage Centenary 1899-1999 Newsletter, no 1, May 1999.

${ }^{125}$ Kevin Alsop, 'The Women's suffrage pavilion'; Julia Berney, 'Memorials to the past play a role in the present'; Geoffrey E. Summerhayes, 'The Pioneer Women's memorial Fountain', For People and Plants, Newsletter of the Friends of King's Park, no 29, Autumn 2000.

${ }^{126}$ Crawford and Skene, special edition of Studies in Western Australian History vol 9, 1999, pix. See also Patricia Grimshaw, 'Reading the Silences: Suffrage activists and race in nineteenth century settler societies', in Patricia Grimshaw, Katie Holmes and Marilyn Lake (eds), Women's Rights and Human Rights: International Perspectives, Palgrave, 2001, pp31- 48 ; Vicki Crowley, 'Acts of Memory and Imagination: Reflections on 
Women's Suffrage and the Centenary Celebrations of Suffrage in South Australia in 1994', Australian Feminist Studies, vol 16, no 35, 2001 pp225-40.

${ }^{127}$ Pearce, Museums, Objects and Collections, p258.

${ }^{128}$ Graeme Davison, 'Museums and the burden of national identity', Public History Review, vol 10, 2003, pp8-20; National Museum of Australia, Yesterday Tomorrow, The National Museum of Australia, Canberra, 2001.

${ }^{129}$ Raphael Samuel, Island Stories, London, 1998, p222.

130 Walter Benjamin, 'Theses on the philosophy of History', in H. Arendt (ed), Illuminations , (London: Cape, 1970).

131 Despite emails to the gallery I have yet to receive a response to my initial personal query. See Judith A. Allen, Rose Scott: Vision and revision in feminism, Oxford University Press, Melbourne, 1994, p259-60 for a critique of the exhibition mounted in the Dixson gallery of New South Wales State library to Rose Scott on the sixtieth anniversary of her death in 1985.

132 Lorna Ollif, Louisa Lawson. Henry Lawson's crusading mother, Rigby, Australia, 1978, pp133-4.

133 David A. Weston (ed), The Sleeping City: The Story of Rookwood Necropolis, Hale and Iremonger, Sydney, p122.

${ }^{134}$ CD, Women's Electoral Lobby, Battye Library, Perth. 